\title{
Moss and Lichen Biomonitoring of Atmospheric Pollution in the Western Cape Province (South Africa)
}

\author{
N. B. Ndlovu1,2, M. V. Frontasyeva3 ${ }^{(1)}$, R. T. Newman'1, P. P. Maleka² \\ ${ }^{1}$ Department of Physics, Faculty of Natural Sciences, Stellenbosch University, Cape Town, Republic of South Africa \\ ${ }^{2}$ Department of Subatomic Physics, iThemba LABS, Cape Town, Republic of South Africa \\ ${ }^{3}$ Sector of Neutron Activation Analysis and Applied Research, Frank Laboratory of Neutron Physics, Joint Institute for Nuclear \\ Research, Dubna, Russian Federation \\ Email: marina@nf.jinr.ru
}

How to cite this paper: Ndlovu, N.B., Frontasyeva, M.V., Newman, R.T. and Maleka, P.P. (2019) Moss and Lichen Biomonitoring of Atmospheric Pollution in the Western Cape Province (South Africa). American Journal of Analytical Chemistry, 10, 86-102.

https://doi.org/10.4236/ajac.2019.103008

Received: January 29, 2019

Accepted: March 5, 2019

Published: March 8, 2019

Copyright $\odot 2019$ by author(s) and Scientific Research Publishing Inc. This work is licensed under the Creative Commons Attribution International License (CC BY 4.0).

http://creativecommons.org/licenses/by/4.0/

\begin{abstract}
For the first time, the atmospheric deposition of trace elements was investigated in two regions (Cape Winelands and Cape Peninsula) of the Western Cape Province of the Republic of South Africa (RSA) using naturally growing mosses and lichens. A total of 33 elements were determined by epithermal instrumental neutron activation analysis (INAA). Multivariate statistical analysis was used to identify and characterize different pollution sources.
\end{abstract}

\section{Keywords}

Atmospheric Deposition, Trace Elements, Mosses, Lichens, Instrumental Neutron Activation Analysis, Multivariate Statistical Analysis

\section{Introduction}

The use of lichens as indicators of healthy air dates back to 1866 when Nylander [1] evaluated air quality based on changes observed in the lichen community composition at Jardin du Luxembourg in Paris [2]. Since then, the process of assessing changes in lichen community composition in order to evaluate "air quality" became one of the most used tools in most European countries [3] [4]. However, this technique of using biological material to monitor the environment, i.e. biomonitoring, only became well established across the world following the ground-breaking work by Rühling and Tyler in the late 1960s, introducing the use of naturally growing mosses as monitors of heavy metal deposition from the atmosphere [2] [3] [4] [5]. At present, this technique is well-established 
in most European countries [2]-[10] but not in South Africa (SA). Thus far, there are five published biomonitoring studies in South Africa [11] [12] [13] [14] [15]. These are related to data acquired from Pretoria region (Gauteng Province) [11] [14] and from a mining industrial area in the North West Province of SA [15].

Apart from monitoring concentration levels of classical pollutants such as particulate matter $\left(\mathrm{PM}_{10}\right)$, ozone $\left(\mathrm{O}_{3}\right)$, carbon monoxide $(\mathrm{CO})$, little is being done by the SA government on air monitoring of other pollutants such as heavy metals and other trace elements. However, any industrialised and developing country like SA carries a burden of industrial air pollution, including trace elements (e.g. heavy metals) and persistent organic pollutants. As identified by the SA Department of Environmental Affairs and Tourism (2000), emissions from the industry contribute to high levels of air pollution and waste in SA [16]. A variety of adverse effects on human health and environmental degradation experienced in developing as well as developed countries are related to exposure to polluted air [17] [18] [19]. Primary and major causes of air pollution include consistent industrial growth, urbanisation, and emissions from automobile traffic [5] [20] [21].

The choice of biomonitors for the current study was based on the enhanced ability of mosses and lichens to trap, accumulate, and retain heavy metals and other trace elements from the air [21]-[26]. This is due to their lack of a root system which causes them to absorb water, nutrients, and contaminants from wet and dry atmospheric deposition over the entire surface. This leads to their insignificant soil contamination or uptake of nutrients from the substrate, which might affect the concentrations of trace metals found in mosses and lichens [3] [10] [21]. The only exception is when mosses or lichens grow directly on mineral soil, since that makes it challenging to avoid co-sampling of mineral soil particles adhering to the moss tissue. In that case, sampling of mosses and lichens growing directly on mineral soil should be avoided.

Mosses and lichens are two completely unrelated groups of cryptogamic organisms with a number of features in common. Apart from lacking a root system, these organisms also lack thick waxy cuticles, have a high surface/mass ratio, grow slowly (usually for years) and show high retention of atmospheric metals [27] [28]. The moss and lichen species used in this study were selected according to their abundance in the study area. Overall, mosses and lichens were used as natural air filters to trap the toxic trace elements from the air. These natural air filters were then analysed by non-destructive INAA in order to determine trace element concentrations.

Analytical techniques routinely used in biomonitoring studies include INAA, AAS (atomic absorption spectrometry), ICP-MS/AES (inductively coupled plasma-mass spectrometry/atomic emission spectrometry), etc. Among these INAA is preferred in many cases because of its high accuracy. However, a main drawback of nuclear physics techniques is that they are expensive, relatively difficult to calibrate, and have a relatively low throughput [17] [29] [30] [31] [32]. 
In general, INAA is a highly sensitive non-destructive analytical technique used to perform both qualitative and quantitative multi-element analysis of major, minor, and trace elements as well as rare-earth elements (REE) in samples from almost every conceivable scientific or technical field [33] [34] [35]. Since 2007, it was established as the powerful primary (reference) analytical technique of measurement to determine the International System of Units (SI) traceable values of element content in complex samples. This is due to its potential for a superior accuracy and reliability over alternative non-nuclear techniques in providing quantification of trace elements at ultralow detection limits in environmental, biological and geological multi-element studies [30] [35] [36] [37] [38]. The most common and preferred reactions that are mostly utilised to determine trace elements in biological materials using NAA are $(n, \gamma)$ reactions because of the generally higher sensitivity achieved from them as compared to other reactions [33] [39] [40].

This paper presents the first survey of moss and lichen biomonitoring of atmospheric deposition of trace and other toxic elements conducted in the Western Cape province of SA.

\section{Materials and Methods}

\section{1) Study Area}

The study area is situated in the south-western part of SA. It comprises two parts of the Western Cape province; the Cape Winelands (Stellenbosch-Franschhoek) and the Cape Peninsula (Signal Hill-False Bay-Betty's Bay). In general, Western Cape province exhibits diverse climatological conditions which are influenced by both the Indian (warm water) and Atlantic (cold water) oceans. However, the specific area where this study was conducted is considered to have a Mediterranean climate with cool and wet winters (from June until August) and warm and dry summers (from December until February). For this study, sampling was done during March-April 2012. Figure 1 shows the SA map with the Western Cape province indicated in red in the south-western corner. The enlarged area illustrates sampling sites where mosses and lichens were collected for the current study [41] [42].

Air pollution monitoring as well as air quality control (for classical pollutants) in the Western Cape province is managed by the air pollution management directorate of the Department of Environmental Affairs and Development Planning (DEADP). This monitoring of classical pollutants levels happens continuously at both provincial and local government levels in order to evaluate them against those national standards [43].

The Cape Winelands air quality is mostly considered to be good. However, some parts of Stellenbosch, Wellington and Paarl tend to experience noticeable levels of air pollution. These are associated with emissions from motor vehicles, industrial and manufacturing sources, agricultural emissions (from wine farms), residential fuel burning and biomass burning emissions, as well as emissions from landfill and wastewater treatment plants. In addition, dominant southerly 


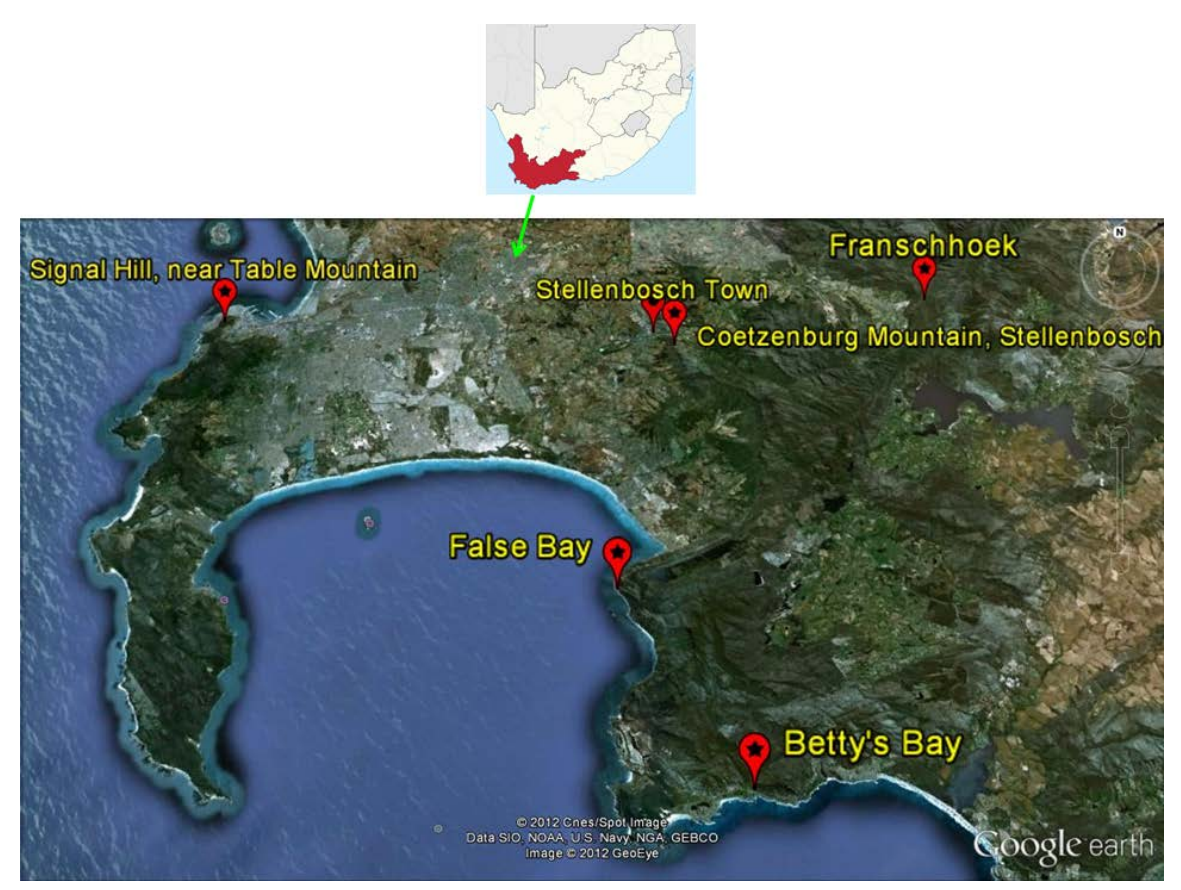

Figure 1. Study area [41] [42].

winds (particularly in winter) usually transport air pollutants from the City of Cape Town to the southern parts of the Cape Winelands [43]. Currently, there are six industries which can be regarded as potential air pollution sources around Stellenbosch Municipality (see Table 1). This is due to their use of fuel burning devices. Their locations are shown in Figure 2. Amongst other things, these industries specialise in manufacturing and processing of chemicals, bricks, planks, wines and agri-food products as well as waste burning [44].

Due to the fact that there are no heavy factories or heavy industries situated in Franschhoek, except for agricultural industry, Franschhoek is one of the areas which are generally considered to be relatively pollution free in the Cape Wineland [45]. On the other hand, air pollution along the False Bay and Betty's Bay is mainly caused by vehicle emissions, particularly from diesel-driven vehicles. In addition, some vehicle emissions accumulated over Cape Town are transported out by north-westerly winds over to False Bay. The bulk of the development in False Bay and Betty's Bay is residential; there is basically negligible effect of emissions from heavy industries since none are found in these coastlines. Similar for Signal Hill, there are no sources of atmospheric pollution to be found on the hill itself. However, pollutants from the Cape Town city can be transported out by the winds over to Signal Hill [46] [47]. Moreover, the Signal Hill, False Bay and Betty's Bay which are located much closer to the ocean are more likely to be affected by emissions from the ocean.

\section{2) Sampling and Sample Preparation for Irradiation}

The moss species Leptodon smithii and lichen species Parmotrema perlatum were used as biomonitors in this study. Sampling was carried out during the warm and dry summer season (March-April) of 2012 from 5 sampling sites in 


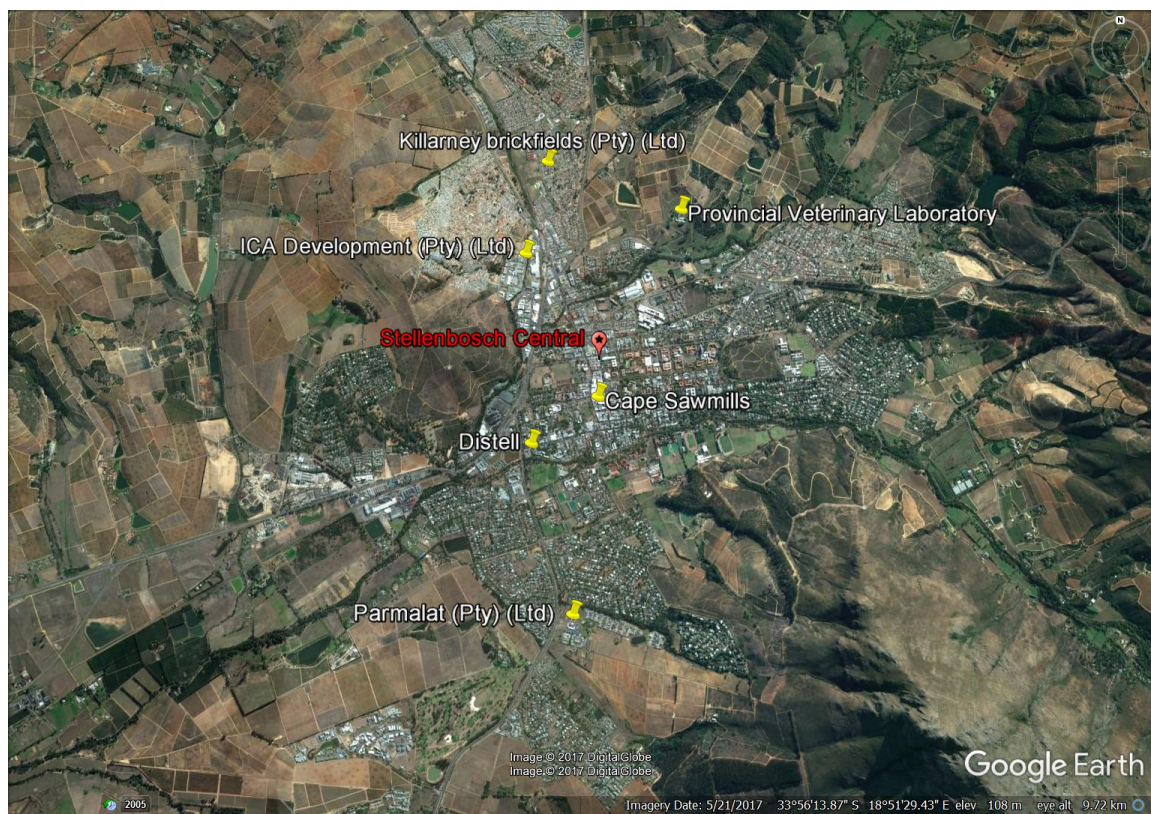

Figure 2. Potential air pollution sources in Stellenbosch [42].

Table 1. Potential air pollution sources around Stellenbosch municipality [44].

\begin{tabular}{lcc}
\hline \multicolumn{1}{c}{ Company Name } & Nature of Process & Device Type \\
\hline 1) Cape Sawmills & Sawmills & Boilers: Wood waste and coal \\
2) Distell & Winery & Boilers: Coal and heavy fuel oil \\
3) ICA Development Pty Ltd. & Chemical Manufacture & Air heater: Diesel \\
4) Killarney brickfields Pty Ltd. & Brick Manufacture & Boilers: Coal \\
5) Parmalat Pty Ltd. & Cheese Manufacture & Boilers: Heavy fuel oil \\
6) Provincial Veterinary & Veterinary Incinerator & Incinerator: Diesel
\end{tabular}

the Western Cape province of SA. A total of 30 samples of mosses (14 samples) and lichens (16 samples) were collected from the areas shown in Figure 1. Sampling was conducted according to the sampling guidelines provided by the UNECE ICP Vegetation Programme on atmospheric deposition studies in Europe [47]. During the sampling period for the current study, the study area did not have an abundance of mosses. In general, lichens were found to be more abundant as compared to mosses. This is because apart from their ability to accumulate air pollutants, lichens possess an exceptional capability to grow in abundance and survive in most geographical even in areas that are usually regarded as highly toxic where few, if any, higher plants survive [48] [49] [50]. Sampling of moss and lichen samples was conducted in such a way that it was representative of the whole study area. Samples were not washed but cleaned by removing surface contamination of all external plant material and visible soil contamination. All samples were dried to constant weight at room temperatures and all extraneous plant material was removed. Samples of about $0.3 \mathrm{~g}$ in dry weight were pelletized, wrapped with plastic covers and packed in polyethylene 
cups for short-term irradiation in order to determine short-lived isotopes. For long-term irradiation, which is used for determination of long-lived isotopes, samples were wrapped with aluminium foils and packed in aluminium cups. Samples were then sorted and sent for irradiation.

\section{3) Sample Analysis}

NAA was performed in the radioanalytical complex REGATA using fast pulsed reactor IBR-2 at the Frank Laboratory of Neutron Physics (FLNP) of the Joint Institute for Nuclear Research (JINR) in Dubna, Russia. As shown in Table 1, long-term irradiation was performed using a cadmium-screened irradiation channel with average neutron flux density $\left(\phi_{\text {epi. }}\right)=3.6 \times 10^{11} \mathrm{n} /\left(\mathrm{cm}^{2} \cdot \mathrm{s}\right)$ in order to determine long-lived isotopes. Samples were irradiated for 4 days, repacked for cooling and then measured twice. Gamma-ray spectroscopy measurements were performed using using an HPGe detector system coupled with Genie2000 analysis software. The first measurements were taken after 4 - 6 days cooling time for 30 minutes immediately after repacking. Subsequently, after another cooling time of 20 days, the $2^{\text {nd }}$ measurements were taken for 1.5 hours. To determine short lived isotopes ( $\mathrm{Al}, \mathrm{Ca}, \mathrm{Cl}, \mathrm{I}, \mathrm{Mg}, \mathrm{Mn}$, and $\mathrm{V}$ ), a conventional irradiation channel utilizing the full energy spectrum of neutrons from the reactor, as shown in Table 2, was used. Samples were irradiated for 3 minutes and gamma spectra were recorded twice; after 2 - 3 minutes and 9 - 10 minutes of decay time, respectively.

Data processing of carrying out qualitative and quantitative analysis of elements, which is conducted on the basis of standard reference materials (SRM) and flux comparators, was done using software developed at FLNP. The concentrations of the environmentally meaningful elements; $\mathrm{Pb}, \mathrm{Cu}$ and $\mathrm{Cd}$, could not be determined by INAA. These elements were therefore determined using inductively coupled plasma mass-spectrometry (ICP-MS) at the Central Analytical Facilities (CAF), Stellenbosch University, Stellenbosch.

\section{Results and Discussion}

In this study, a total of 33 elements ( $\mathrm{Na}, \mathrm{Mg}, \mathrm{Al}, \mathrm{K}, \mathrm{Ca}, \mathrm{V}, \mathrm{Cr}, \mathrm{Mn}, \mathrm{Fe}, \mathrm{Co}, \mathrm{Zn}$, As, Se, Sr, Ba, Br, Rb, Sb, I, Cs, Cl, Sc, Ti, La, Ce, Nd, Sm, Tb, Hf, Ta, W, Th, U) were determined using INAA. In order to identify and characterize different pollution sources, multivariate statistics (factor analysis) was applied on the acquired data. Factor loadings of selected elements concentrations for the samples analysed in this study are given in Table 3.

Table 2. Neutron flux in REGATA irradiation channels [51].

\begin{tabular}{|c|c|c|c|c|c|c|}
\hline & \multicolumn{3}{|c|}{ Ch. 1 neutron flux $\left(\mathrm{n} \cdot \mathrm{cm}^{-2} \cdot \mathrm{s}^{-1}\right)$} & \multicolumn{3}{|c|}{ Ch. 2 neutron flux $\left(\mathrm{n} \cdot \mathrm{cm}^{-2} \cdot \mathrm{s}^{-1}\right)$} \\
\hline & \multicolumn{3}{|c|}{$\begin{array}{l}\text { Channel diameter }=28 \mathrm{~mm} \text {, } \\
\text { Channel length }=260 \mathrm{~mm}\end{array}$} & \multicolumn{3}{|c|}{$\begin{array}{l}\text { Channel diameter }=28 \mathrm{~mm} \text {, } \\
\text { Channel length }=260 \mathrm{~mm}\end{array}$} \\
\hline & Thermal & Resonance & Fast & Thermal & Resonance & Fast \\
\hline Experimental value & Cd-coated & $3.6 \times 10^{11}$ & $5.5 \times 10^{11}$ & $1.5 \times 10^{11}$ & $1.8 \times 10^{11}$ & $2.7 \times 10^{11}$ \\
\hline
\end{tabular}


Table 3. Factor analysis of NAA data on moss samples collected from the Western Cape Province of South Africa (Varimax normalized).

\begin{tabular}{|c|c|c|c|c|}
\hline Variables & Factor 1 & Factor 2 & Factor 3 & Factor 4 \\
\hline $\mathrm{Mg}$ & 0.27 & 0.32 & 0.40 & 0.28 \\
\hline $\mathrm{Al}$ & 0.80 & -0.17 & 0.28 & 0.08 \\
\hline $\mathrm{K}$ & 0.70 & 0.42 & -0.12 & -0.02 \\
\hline $\mathrm{Ca}$ & -0.19 & 0.36 & -0.29 & 0.63 \\
\hline $\mathrm{V}$ & 0.69 & 0.25 & 0.57 & 0.01 \\
\hline $\mathrm{Cr}$ & 0.60 & 0.47 & 0.36 & 0.09 \\
\hline $\mathrm{Mn}$ & 0.64 & 0.31 & -0.47 & -0.01 \\
\hline $\mathrm{Fe}$ & 0.78 & 0.53 & 0.25 & -0.01 \\
\hline Co & 0.67 & 0.59 & -0.05 & -0.13 \\
\hline $\mathrm{Zn}$ & 0.22 & 0.82 & 0.07 & 0.17 \\
\hline As & 0.48 & 0.79 & 0.00 & -0.03 \\
\hline $\mathrm{Se}$ & -0.13 & 0.06 & 0.59 & -0.53 \\
\hline $\mathrm{Sr}$ & 0.13 & 0.16 & -0.03 & 0.88 \\
\hline $\mathrm{Br}$ & 0.10 & 0.09 & 0.65 & 0.57 \\
\hline $\mathrm{Rb}$ & 0.85 & 0.24 & -0.25 & -0.14 \\
\hline $\mathrm{Sb}$ & 0.05 & 0.68 & 0.19 & 0.06 \\
\hline I & -0.14 & 0.13 & 0.86 & -0.10 \\
\hline Cs & 0.89 & 0.32 & -0.11 & -0.10 \\
\hline $\mathrm{Cl}$ & -0.10 & -0.09 & 0.68 & 0.39 \\
\hline $\mathrm{Sc}$ & 0.91 & 0.19 & 0.16 & -0.11 \\
\hline $\mathrm{Ti}$ & 0.94 & -0.07 & 0.14 & 0.06 \\
\hline $\mathrm{La}$ & 0.96 & 0.07 & 0.13 & 0.04 \\
\hline $\mathrm{Ce}$ & 0.97 & 0.10 & 0.05 & 0.00 \\
\hline $\mathrm{Tb}$ & 0.97 & 0.18 & -0.02 & 0.00 \\
\hline $\mathrm{Hf}$ & 0.92 & 0.15 & -0.14 & 0.13 \\
\hline $\mathrm{Ta}$ & 0.91 & 0.25 & -0.14 & 0.05 \\
\hline $\mathrm{W}$ & 0.93 & 0.20 & 0.09 & 0.01 \\
\hline Th & 0.92 & 0.31 & -0.08 & -0.10 \\
\hline $\mathrm{U}$ & 0.88 & 0.28 & -0.05 & 0.01 \\
\hline Expl. Var & 24.09 & 3.81 & 2.84 & 2.16 \\
\hline Prp. TotP & 0.49 & 0.13 & 0.10 & 0.07 \\
\hline
\end{tabular}

${ }^{1}$ Explored variance.

${ }^{2}$ Total proportion. 
In order to work out values of the factors, the Varimax method was used for orthogonal rotation of variables that were standardized to zero mean and unit standard deviation. Varimax normalized rotation of factors was applied and all factor loadings higher than 0.5 are clearly marked in Table 3 . Varimax normalised factor loadings (in \%) indicate the percentage measure of variability among presented variables under the same factor [52] [53] [54].

The strongest factor here is Factor 1, with an explained variance of $24 \%$. This factor has particularly high values of $\mathrm{Al}, \mathrm{V}, \mathrm{Mn}, \mathrm{Fe}, \mathrm{Co}, \mathrm{Rb}, \mathrm{Cs}, \mathrm{Ti}, \mathrm{Hf}, \mathrm{Ta}, \mathrm{W}$, $T h, U$ and rare-earth elements. These elements indicate contamination of the analysed samples with crustal material attached to the moss and lichen samples. Another potential source of these elements is fly-ash particles produced by processes such as coal burning, which may have a major chemical element composition similar to crustal material [10] [55] [56]. This suggests Distell and Killarney brickfields (Pty) Ltd. plants (both in Stellenbosch) as pollution sources due to heavy fuel oils and coals used by boilers in the manufacturing processes. With an explored variance of about 4\%, Factor 2 has high factor loadings for $\mathrm{Fe}$, $\mathrm{Co}, \mathrm{Zn}, \mathrm{As}$ and $\mathrm{Sb}$. This is a mixture of elements which could be attributed to a basaltic component $(\mathrm{Fe}, \mathrm{Co})$, elements which are associated with soil contamination with mixed geogenic-anthropogenic activities (As, Sb), and elements whose high contents are mainly influenced by natural factors like lithological background ( $\mathrm{Zn})$. In addition, anthropogenic activities also contribute to high concentrations of these elements in air. Hence, the variability of elements in this group represents anthropogenic (man-made) geochemical association, which is highly connected with the industrial activities around the Western Cape region [10] [57] [58] [59]. Factor 3, with an explored variance of about 3\%, has high loadings for V, Se, Br, I, Cl. Except for V, which is associated with dust particles contaminated with oil and vehicle emissions, elements in this factor are associated with atmospheric deposition of aerosols influenced by marine environment processes [10] [55]. In Factor 4 (Ca, Se, Sr, Br) has an explored variance of about $2 \%$. This factor seems to be made by a mixture of elements which could be attributed to terrestrial, marine and industrial pollution. This indicates the presence of crustal material, flysch (a sequence of sedimentary rocks that is deposited in a deep marine facies in the foreland basin of a developing orogen) sediments (from Betty's Bay, False Bay and Signal Hill samples), as well as anthropogenic sources (from Stellenbosch samples) that can be found around the Western Cape area [10] [55] [58] [60].

Average concentrations of elements (major, essential, potentially toxic and REE) in the analysed mosses in this study showed low elemental concentrations to be generally obtained from the Betty's Bay samples. In addition, no observed clear trend of which area (between Stellenbsoch town, Coetzenburg mountain and False Bay) has the highest elemental concentrations (Figures 3(a)-(d)). Contrary to the common trends observed for the elements mentioned above, halogens were observed to have elevated concentrations for samples collected from Betty's Bay and False Bay (Figure 3(e)). 


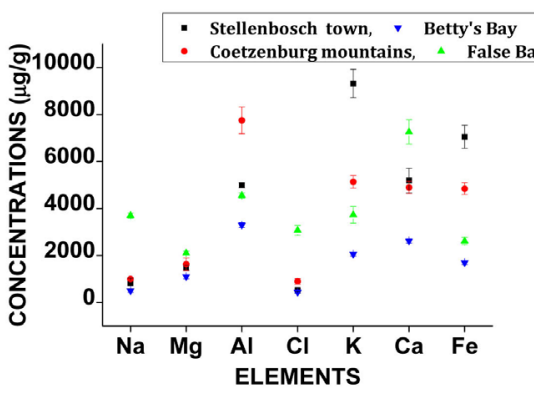

(a)

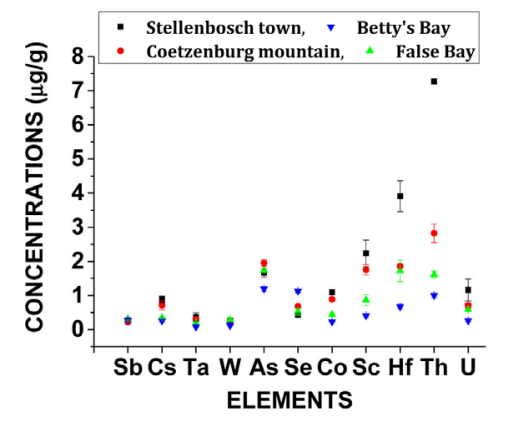

(c)

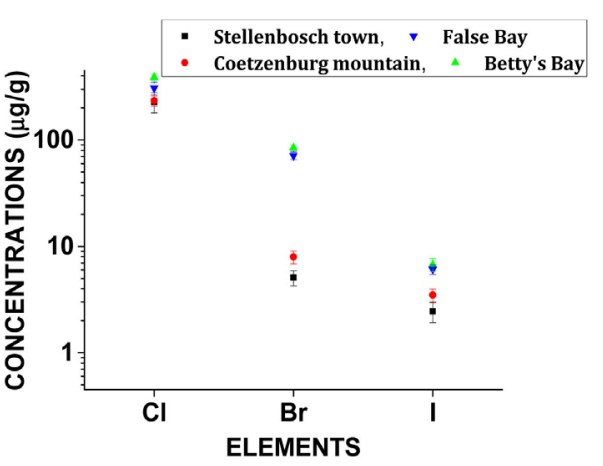

(e)

Figure 3. (a)-(e) Graphs of elemental concentrations for major elements, essential elements, potentially toxic elements, REE, as well as halogens (respectively) in moss samples. The error bars represent the calculated uncertainty $\left(\sigma_{C_{\text {sample }}}\right){ }^{3}$ of the element concentration in the sample [51].

These are the areas that were in relative close proximity to the ocean as compared to Stellenbosch town (Victoria Street) and Coetzenburg mountain. In previous studies (e.g. [61] [62] [63]), it has been proven that an ocean is a source of halogens since halogen are an indication of emissions from sea-salt aerosols from the ocean surface.

${ }^{3} \sigma_{C_{\text {sample }}}=C_{\text {sample }} \sqrt{\left(\frac{\sigma_{1}}{A_{\text {sample }}}\right)^{2}+\left(\frac{\sigma_{2}}{A_{\text {cert. ref. mat. }}}\right)^{2}+\left(\frac{\sigma_{3}}{C_{\text {cert. ref. mat. }}}\right)^{2}}$, where; $\sigma_{C_{\text {sanple }}}=$ uncertainty of the measured element concentration in the sample $\left(C_{\text {sample }}\right), \sigma_{1}=$ uncertainty of the measured activity in the sample $\left(A_{\text {sample }}\right), \sigma_{2}=$ uncertainty of the measured activity in the certified reference material, $\sigma_{3}=$ uncertainty of the element concentration in the certified reference material as listed on the certificate. 
For lichens, low elemental concentrations were generally found in samples collected from Franschoek. This trend same trend was observed for the major, essential, potentially toxic, and the toxic trace elements (Figures 4(a)-(d)). However, halogens were observed to have elevated concentrations for samples collected from Signal Hill (Figure 4(e)).

As compared to Stellenbosch town, Jan Marais Nature Reserve, Coetzenburg mountain and Franschoek sampling areas, Signal Hill area is in relative close proximity to the ocean. That means for both moss and lichen samples, areas closer to the ocean had higher halogen concentrations.

In order to compare some of our moss data with the European data [64], metal median concentrations were plotted alongside corresponding European data (Figures 5(a)-(f)).

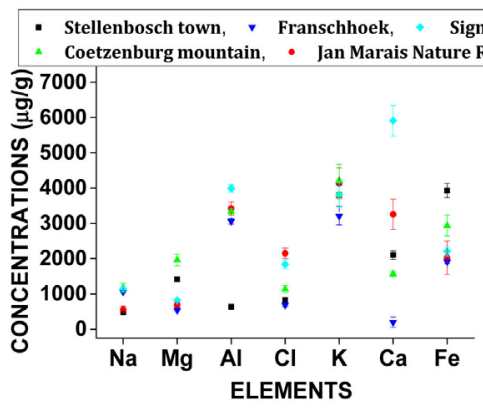

(a)

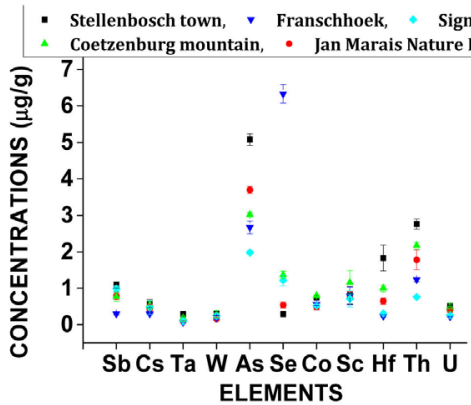

(c)

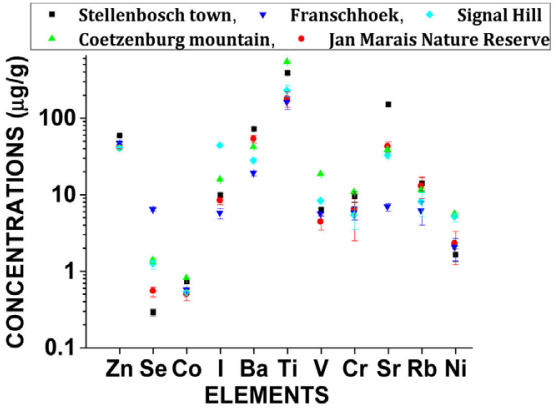

(b)

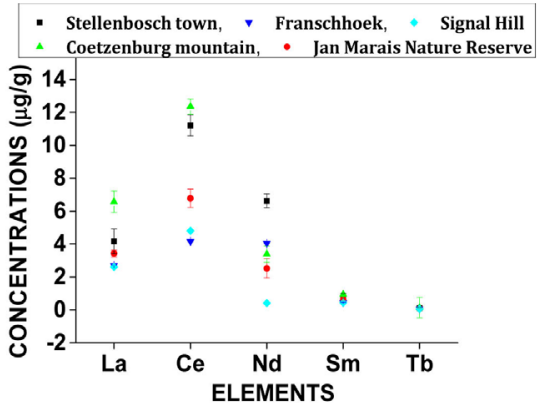

(d)

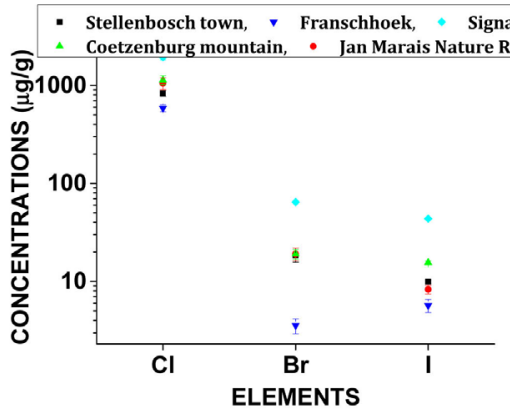

(e)

Figure 4. (a)-(e) Graphs of elemental concentrations for major elements, essential elements, potentially toxic elements, REE as well as halogens (respectively) in lichen samples. The error bars represent the calculated uncertainty of the element concentration in the sample [51]. 


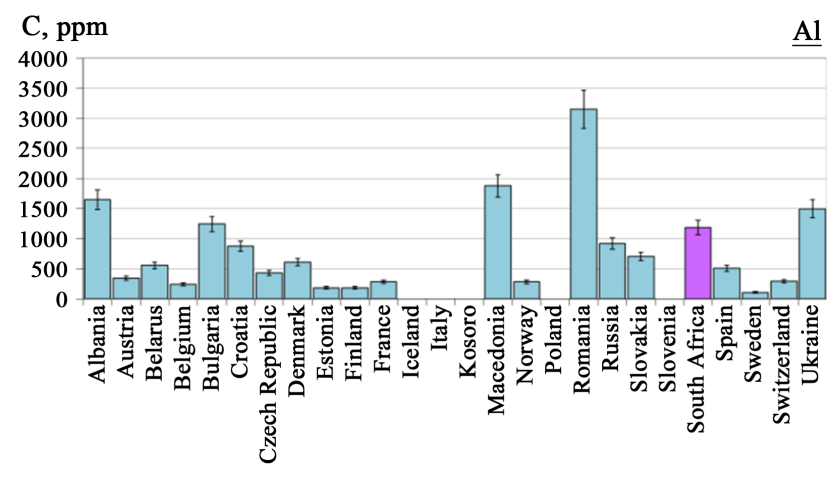

(a)

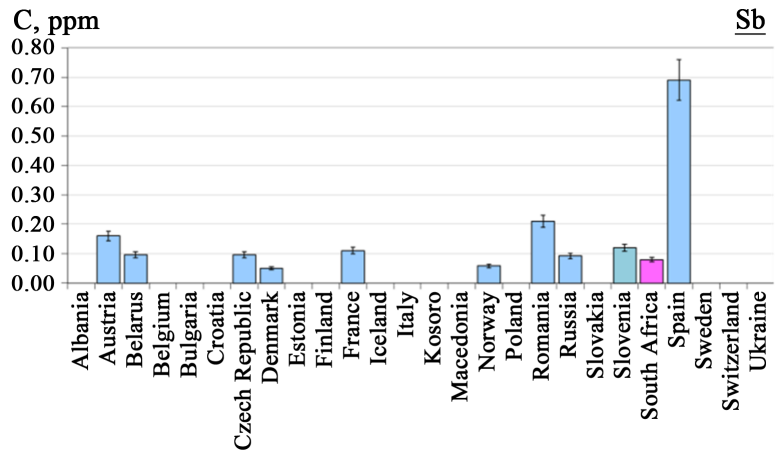

(c)

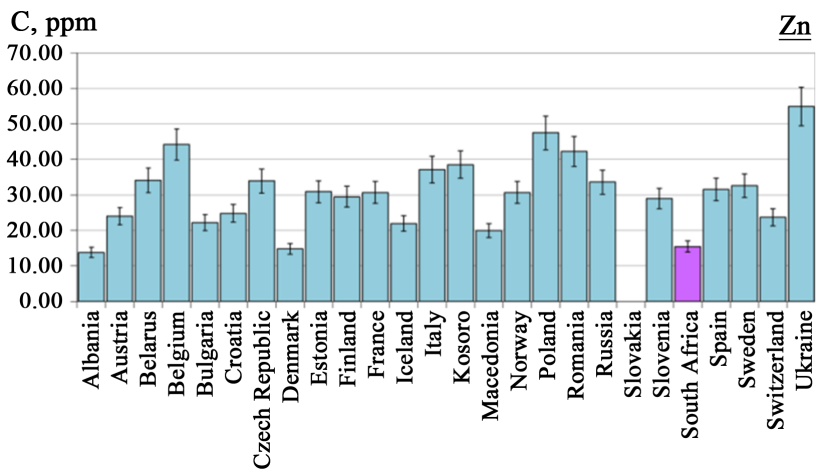

(e)

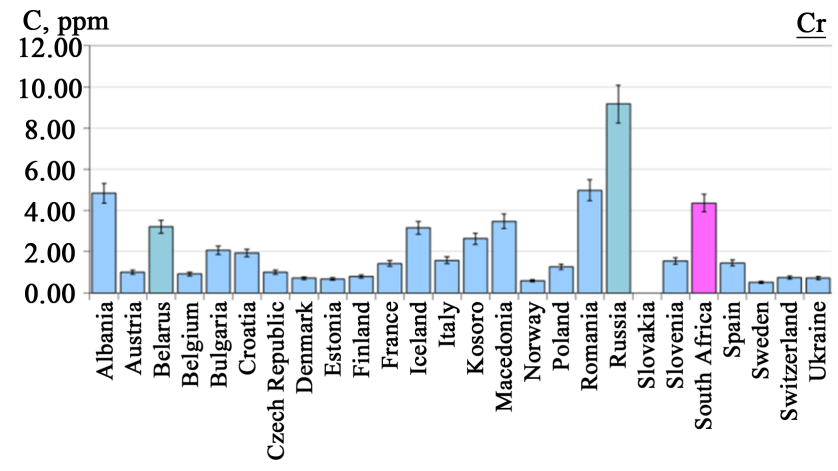

(b)

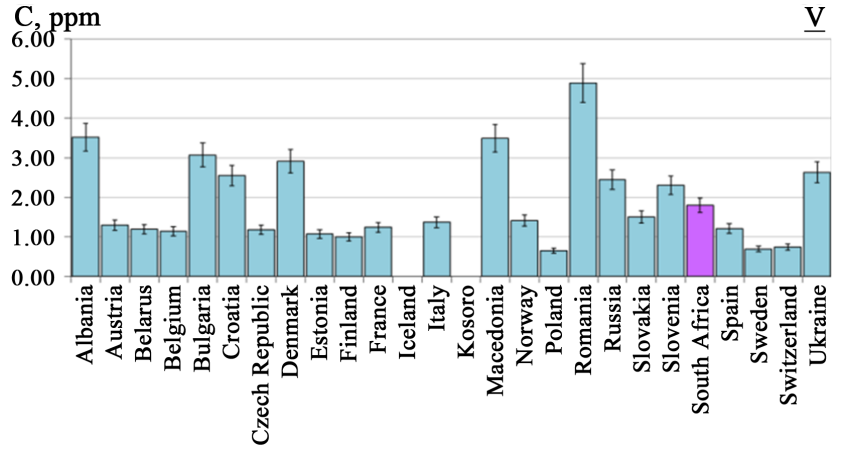

(d)

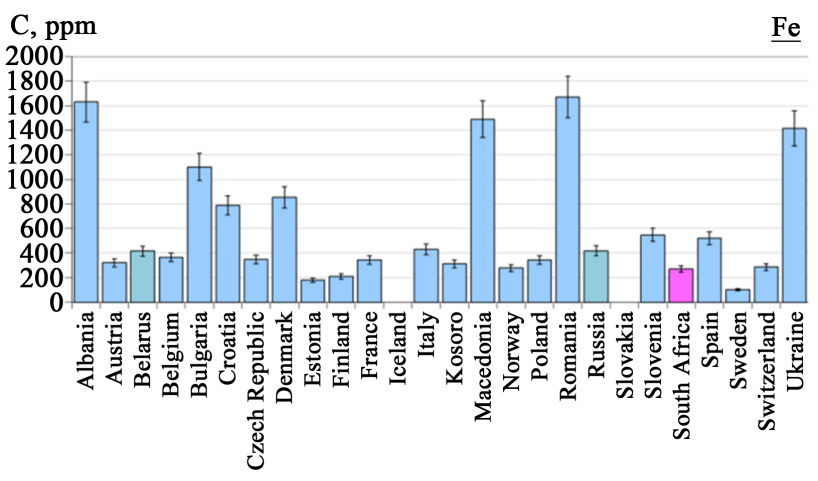

(f)

Figure 5. (a)-(f) Comparing median concentrations of $\mathrm{Al}, \mathrm{Cr}, \mathrm{Sb}, \mathrm{V}, \mathrm{Zn}$ and $\mathrm{Fe}$ in moss samples from the Western Cape, South Africa with corresponding European data [64].

\section{Conclusion}

Our results indicated that mosses are generally more efficient than lichens at accumulating major, essential, potentially toxic and rare-earth elements. However, complementary results were achieved by using both mosses and lichens. This is because lichens were found to be more efficient in accumulating halogens as compared to mosses. Descriptive statistics of the acquired data were generated and correlation analyses were done using the Statistica ${ }^{\mathrm{TM}}$ package. This was done in order to facilitate the identification and characterization of different pollution sources from the collected sample element content. Concentrations of toxic elements obtained in samples from Stellenbosch town and Coetzenburg mountain 
(also in Stellenbosch) were found to be relatively higher than those found in samples from Signal Hill, Franschoek, Betty's Bay and False Bay. Higher concentration of elements in samples collected from Stellenbsoch town and Coetzenburg mountain can be attributed to the industries (potential air pollution sources) around Stellenbosch Municipality (see Table 1 and Figure 2). Since there are no heavy factories or heavy industries situated in Signal Hill, Franschhoek, False Bay and Betty's Bay; air pollution along these areas is mainly caused by vehicle emissions. This can be caused either by vehicles driven in those areas or by dominant winds that usually transport air pollutants from one area to another in the Western Cape. Our results also confirmed elevated concentration levels for halogens $(\mathrm{Cl}, \mathrm{I}, \mathrm{Br})$ in areas closest to the ocean. In general, a comparison of median heavy metal (most toxic air pollutants) concentrations in biomonitors from the Western Cape region with those from Europe revealed relatively lower concentrations for the Western Cape.

\section{Acknowledgements}

Authors express their deep gratitude to Prof. Eiliv Steinnes (Norwegian University of Science and Technology, Trondheim, Norway) for useful discussions and to the National Research Foundation (NRF) of SA for a grant under the South Africa-JINR programme. The NRF-iThemba LABS and Stellenbosch University are also acknowledged for additional funding. The Western Cape Nature Conservation Board is acknowledged for the permission to collect samples (permit No. AAA008-00104-0028). We are thankful to the staff of Sector of NAA and Applied Research of FLNP JINR for help in NAA of samples in question. We also thank the Environmental Analysis Laboratory of the CAF of Stellenbosch University for helping with ICP-MS measurements.

\section{Conflicts of Interest}

The authors declare no conflicts of interest regarding the publication of this paper.

\section{References}

[1] Nylander, M.W. (1866) Les Lichens Du Jardin Du Luxembourg. Bulletin de la Société Botanique de France, 13, 364-371. https://doi.org/10.1080/00378941.1866.10827433

[2] Rühling, Å. and Tyler, G. (1968) An Ecological Approach to the Lead Problem. Botaniska Notiser, 121, 321-342.

[3] Bargagli, R. (2016) Moss and Lichen Biomonitoring of Atmospheric Mercury: A Review. Science of the Total Environment, 572, 216-231. https://doi.org/10.1016/j.scitotenv.2016.07.202

[4] Aničić, M.U., Gordana, V. and Milica, T. (2016) Biomonitoring of Air Pollution Using Mosses and Lichens: A Passive \& Active Approach-State of the Art Research \& Perspectives. Air, Water and Soil Pollution Science and Technology Series, Nova Science Publishers Inc., UK. 
[5] Smodiš, B. (2003) Biomonitoring of Atmospheric Pollution (WITH EMPHASIS ON TRACE ELEMENTS)-BioMAP II. International Atomic Energy Agency, IAEA, Austria.

[6] Berg, T. and Steinnes, E. (1997) Use of Mosses (Hylocomium splendens and Pleurozium schreberi) as Biomonitors of Heavy Metal Deposition: From Relative to Absolute Deposition Values. Environmental Pollution, 98, 61-71.

https://doi.org/10.1016/S0269-7491(97)00103-6

[7] Giordano, S., Adamo, P., Monaci, F., Pittao, E., Tretiach, M. and Bargagli, R. (2009) Bags with Oven-Dried Moss for Active Monitoring of Airborne Trace Elements in Urban Areas. Environmental Pollution, 157, 2798-2805.

https://doi.org/10.1016/j.envpol.2009.04.020

[8] Aboal, J.R., Fernández, J.A., Boquete, T. and Carballeira, A. (2010) Is It Possible to Estimate Atmospheric Deposition of Heavy Metals by Analysis of Terrestrial Mosses? Science of the Total Environment, 408, 6291-6297.

https://doi.org/10.1016/j.scitotenv.2010.09.013

[9] Nickel, S., Hertel, A., Pesch, R., Schröder, W. and Steinnes, E. (2014) Modelling and Mapping Spatio-Temporal Trends of Heavy Metal Accumulation in Moss and Natural Surface Soil Monitored 1990-2010 throughout Norway by Multivariate Generalized Linear Models and Geostatistics. Atmospheric Environment, 99, 85-93. https://doi.org/10.1016/j.atmosenv.2014.09.059

[10] Frontasyeva, M.V. (2011) Neutron Activation Analysis in the Life Sciences. Physics of Particles and Nuclei, 42, 332-378. https://doi.org/10.1134/S1063779611020043

[11] Olowoyo, J.O., van Heerden, E., Fischer, J.L. and Baker, C. (2010) Trace Metals in Soil and Leaves of Jacaranda mimosifolia in Tshwane Area, South Africa. Atmospheric Environment, 44, 1826-1830. https://doi.org/10.1016/j.atmosenv.2010.01.048

[12] Olowoyo, J.O., Van Heerden, E. and Fischer, J.L. (2011) Trace Element Concentrations from Lichen Transplants in Pretoria, South Africa. Environmental Science and Pollution Research, 18, 663-668. https://doi.org/10.1007/s11356-010-0410-3

[13] Forbes, P.B.C., Thanjekwayo, M., Okonkwo, J.O., Sekhula, M. and Zvinowanda, C. (2009) Lichens as Biomonitors for Manganese and Lead in Pretoria, South Africa. Fresenius Environmental Bulletin, 18, 609-614.

[14] Van der Wat, L. and Forbes, P.B.C. (2015) Lichens as Biomonitors for Organic Air Pollutants. TrAC Trends in Analytical Chemistry, 64, 165-172.

https://doi.org/10.1016/j.trac.2014.09.006

[15] Olowoyo, J.O., Odiwe, A.I., Mkolo, N.M. and Macheka, L. (2013) Investigating the Concentrations of Different Elements in Soil and Plant Composition from a Mining Area. Polish Journal of Environmental Studies, 22, 1135-1141.

[16] Department of Environmental Affairs and Tourism (2000) Integrated Pollution and Waste Management for South Africa: A Policy on Pollution Prevention, Waste Minimisation, Impact Management and Remediation.

[17] Frontasyeva, M.V. (2009) Nuclear and Related Analytical Techniques for Life Sciences. Ovidius University Annals of Chemistry, 20, 11-18.

[18] World Health Organisation Working Group (2003) Health Aspects of Air Pollution with Particulate Matter, Ozone and Nitrogen Dioxide. Technical Report, World Health Organisation (WHO) Regional Office for Europe.

[19] Tiwary, A. and Williams, I. (2018) Air Pollution: Measurement, Modelling and Mitigation. CRC Press, Boca Raton.

[20] Rühling, A. and Tyler, A. (1971) Regional Differences in the Deposition of Heavy 
Metals over Scandinavia. Journal of Applied Ecology, 8, 497-507. https://doi.org/10.2307/2402886

[21] Jiang, Y., Fan, M., Hu, R., Zhao, J. and Wu, Y. (1105) Mosses Are Better than Leaves of Vascular Plants in Monitoring Atmospheric Heavy Metal Pollution in Urban Areas. International Journal of Environmental Research and Public Health, 15, pii: E1105. https://doi.org/10.3390/ijerph15061105

[22] Mróz, T., Szufa, K., Frontasyeva, M.V., et al. (2018) Determination of Element Composition and Extraterrestrial Material Occurrence in Moss and Lichen Samples from King George Island (Antarctica) Using Reactor Neutron Activation Analysis and SEM Microscopy. Environmental Science and Pollution Research, 25, 436-446. https://doi.org/10.1007/s11356-017-0431-2

[23] Ávila-Pérez, P., Longoria-Gándara, L.C., García-Rosales, G., et al. (2018) Monitoring of Elements in Mosses by Instrumental Neutron Activation Analysis and Total X-Ray Fluorescence Spectrometry. Journal of Radioanalytical and Nuclear Chemistry, 317, 367-380. https://doi.org/10.1007/s10967-018-5896-Z

[24] Steinnes, E., Berg, T. and Uggerud, H.T. (2011) Three Decades of Atmospheric Metal Deposition in Norway as Evident from Analysis of Moss Samples. Science of the Total Environment, 412-413, 351-358. https://doi.org/10.1016/j.scitotenv.2011.09.086

[25] Markert, B., Wuenschmann, S., Fraenzle, S., Wappelhorst, O. and Weckert, V. (2008) On the Road from Environmental Biomonitoring to Human Health Aspects: Monitoring Atmospheric Heavy Metal Deposition by Epiphytic/Epigeic Plants: Present Status and Future Needs. International Journal of Environment and Pollution, 32, 486-498. https://doi.org/10.1504/IJEP.2008.018412

[26] Aničić, M., Tomašević, M., Tasić, M., Rajšić, S., Popović, A., Frontasyeva, M.V., Lierhagen, S. and Steinnes, E. (2009) Monitoring of Trace Element Atmospheric Deposition Using Dry and Wet Moss Bags: Accumulation Capacity versus Exposure Time. Journal of Hazardous Materials, 171, 182-188. https://doi.org/10.1016/j.jhazmat.2009.05.112

[27] González, A.G. and Pokrovsky, O.S. (2014) Metal Adsorption on Mosses: Toward a Universal Adsorption Model. Journal of Colloid and Interface Science, 415, 169-178. https://doi.org/10.1016/j.jcis.2013.10.028

[28] Varela, Z., Fernández, J.A., Real, C., Carballeira, A. and Aboal, J.R. (2015) Influence of the Physicochemical Characteristics of Pollutants on Their Uptake in Moss. Atmospheric Environment, 102, 130-135. https://doi.org/10.1016/j.atmosenv.2014.11.061

[29] De Bruin, D. (1990) Applying Biological Monitors and Neutron Activation Analysis in Studies of Heavy-Metal Air Pollution. IAEA Bulletin, 4, 22-27.

[30] Allajbeu, S., Yushin, N.S., Qarri, F., Duliu, O.G., Lazo, P. and Frontasyeva, M.V. (2016) Atmospheric Deposition of Rare Earth Elements in Albania Studied by the Moss Biomonitoring Technique, Neutron Activation Analysis and GIS Technology. Environmental Science and Pollution Research, 23, 14087-14101. https://doi.org/10.1007/s11356-016-6509-4

[31] Harmens, H. (2010) United Nations Economic Commission for Europe Convention on Long-Range Transboundary Air Pollution: Monitoring of Atmospheric Deposition of Heavy Metals, Nitrogen and POPs in Europe Using Byrophytes. ICP Vegetation Coordination Centre.

[32] Brown, R.J.C. and Milton, M.J.T. (2005) Analytical Techniques for Trace Element Analysis: An Overview. TrAC Trends in Analytical Chemistry, 24, 266-274. 
https://doi.org/10.1016/j.trac.2004.11.010

[33] Bode, P. (1996) Instrumental and Organizational Aspects of a Neutron Activation Analysis Laboratory. PhD Thesis, Delft University of Technology.

[34] Daud, M. (2009) Use of Various Plants as Biomonitors to Estimate Atmospheric Pollution. PhD Thesis, University of the Punjab, Lahore. http://resolver.tudelft.nl/uuid:438b9110-fb94-4015-b277-1c5fba96ac71

[35] Greenberg, R.R. (2008) Pushing the Limits of NAA: Accuracy, Uncertainty and Detection Limits. Journal of Radioanalytical and Nuclear Chemistry, 278, 231-240. https://doi.org/10.1007/s10967-008-9101-7

[36] Glascock, M.D. (2006) An Overview of Neutron Activation Analysis. Technical Report, University of Missouri Research Reactor, Columbia.

[37] Frontasyeva, M.V., Pavlov, S.S. and Shvetsov, V.N. (2010) NAA for Applied Investigations at FLNP JINR: Present and Future. Journal of Radioanalytical and Nuclear Chemistry, 286, 519-524. https://doi.org/10.1007/s10967-010-0814-Z

[38] Frontasyeva, M.V. (2011) NAA for Life Sciences at Frank Laboratory of Neutron Physics, Joint Institute for Nuclear Research in Dubna. Ecological Chemistry and Engineers, 18, 281-304.

[39] Filby, R.H. (1995) Isotopic and Nuclear Analytical Techniques in Biological Systems: A Critical Study Part IX. Neutron Activation Analysis. Technical Report, IUPAC.

[40] Bode, P., Greenberg, R.R. and De Nadai Fernandes, E.A. (2009) Neutron Activation Analysis: A Primary (Ratio) Method to Determine SI-Traceable Values of Element Content in Complex Samples. CHIMIA International Journal for Chemistry, 63, 678-680. https://doi.org/10.2533/chimia.2009.678

[41] Wikipedia (2017) Western Cape. https://en.wikipedia.org/wiki/Western_Cape

[42] Google Earth: Software Version 7.1.5.1557.

[43] Department of Environmental Affairs and Development Planning (2010) Air Quality Management Plan for the Western Cape Province. Technical Report, Provincial Government of the Western Cape.

[44] uMoya-NILU Consulting (Pty) Ltd. (2013) Air Quality Management Plan for the Stellenbosch Municipality. Report No. uMN013-2013.

[45] Willemse, L. (2008) The Extent and Impacts of Land Cover Change in the Franschhoek Valley. Unpublished Honours Project, Department of Geography and Environmental Studies, University of Stellenbosch.

[46] Department of Environmental Affairs and Development Planning (2013) State of Environment Outlook Report for the Western Cape Province: Air Quality Chapter for Public Comment. Technical Report, Western Cape Government.

[47] Harmens, H. (2010) Heavy Metals in European Mosses: 2010 Survey Monitoring Manual. ICP Vegetation Coordination Centre (VCC).

[48] Cocozza, C., Ravera, S., Cherubini, P., Lombardi, F., Marchetti, M. and Tognetti, R. (2016) Integrated Biomonitoring of Airborne Pollutants Over Space and Time Using Tree Rings, Bark, Leaves and Epiphytic Lichens. Urban Forestry \& Urban Greening, 17, 177-191. https://doi.org/10.1016/j.ufug.2016.04.008

[49] Garty, J. (2001) Biomonitoring Atmospheric Heavy Metals with Lichens: Theory and Application. Critical Reviews in Plant Sciences, 20, 309-371. https://doi.org/10.1080/20013591099254

[50] Purvis, O.W. and Pawlik-Skowrońska, B. (2008) Chapter 12 Lichens and Metals. In: 
Stratford, M., Avery, S.V. and Van West, P., Eds., Stress in Yeast and Filamentous Fungi, Volume 27 of British Mycological Society Symposia Series, Academic Press, Cambridge, 175-200.

[51] Frontasyeva, M.V., Dmitriev, A.Y. and Pavlov, S.S. (2012) Automation of Reactor Neutron Activation Analysis. Contract No. 17363.

[52] Davis, J.C. (1986) Statistic and Data Analysis in Geology. Wiley \& Sons, New York.

[53] Filzmoser, P., Garrettb, R.G. and Reimann, C. (2005) Multivariate Outlier Detection in Exploration Geochemistry. Computers \& Geosciences, 31, 579-587. https://doi.org/10.1016/j.cageo.2004.11.013

[54] Reimann, C., Filzmoser, P. and Garrett, R.G. (2002) Factor Analysis Applied to Regional Geochemical Data: Problems and Possibilities. Applied Geochemistry, 17, 185-206. https://doi.org/10.1016/S0883-2927(01)00066-X

[55] Marinova, S., Yurukova, L., Frontasyeva, M.V., Steinnes, E., Strelkova, L.P., Marinov, A. and Karadzhinova, A.G. (2010) Air Pollution Studies in Bulgaria Using the Moss Biomonitoring Technique. Ecological Chemistry and Engineers, 17, 37-52.

[56] Barandovski, L., Trajče, S., Šajn, R., Frontasyeva, M.V. and Bačeva, K. (2013) Air Pollution Study in Macedonia Using Moss Biomonitoring Technique, ICP-AES and AAS. Macedonian Journal of Chemistry and Chemical Engineering, 32, 89-107.

[57] Barandovski, L., Frontasyeva, M.V., Stafilov, T., Šajn, R., Pavlov, S. and Enimiteva, V. (2012) Trends of Atmospheric Deposition of Trace Elements in Macedonia Studied by the Moss Biomonitoring Technique. Journal of Environmental Science and Health, Part A: Toxic/ Hazardous Substances and Environmental Engineering, 47, 2000-2015. https://doi.org/10.1080/10934529.2012.695267

[58] Balabanova, B., Stafilov, T. and Bačeva, K. (2015) Bioavailability and Bioaccumulation Characterization of Essential and Heavy Metals Contents in R. acetosa, S. oleracea and $U$. dioica from Copper Polluted and Referent Areas. Journal of Environmental Health Science and Engineering, 13, 1-22. https://doi.org/10.1186/s40201-015-0159-1

[59] Bačeva, K., Stafilov, T. and Matevski, V. (2014) Distribution and Mobility of Toxic Metals in Thymus alsarensis Ronniger in Allchar As-Sb-Tl Mine, Republic of Macedonia. Plant Biosystems-An International Journal Dealing with all Aspects of Plant Biology, 1-10.

[60] Nguyen-Viet, H., Frontasyeva, M.V., Trinh Thi, T.M., Gilbert, D. and Bernard, N. (2010) Atmospheric Heavy Metal Deposition in Northern Vietnam: Hanoi and Thainguyen Case Study Using the Moss Biomonitoring Technique, INAA and AAS. Environmental Science and Pollution Research, 17, 1045-1052. https://doi.org/10.1007/s11356-009-0258-6

[61] Låg, J. and Steinnes, E. (1976) Regional Distribution of Halogens in Norwegian Forest Soils. Geoderma, 16, 317-325. https://doi.org/10.1016/0016-7061(76)90015-X

[62] Frontasyeva, M.V. and Steinnes, E. (2004) Marine Gradients of Halogens in Moss Studies by Epithermal Neutron Activation Analysis. Journal of Radioanalytical and Nuclear Chemistry, 261, 101-106. https://doi.org/10.1023/B:JRNC.0000030941.78117.77

[63] Badia, A., Reeves, C.E., Baker, A.R., et al. (2017) Importance of Reactive Halogens in the Tropical Marine Atmosphere: A Regional Modelling Study Using WRF-Chem. Atmospheric Chemistry and Physics Discussions, 2017, 1-45. https://doi.org/10.5194/acp-2017-903

[64] Harmens, H., Norris, D., Mills, G. and The Participants of the Moss Survey (2013) 
Heavy Metals and Nitrogen in Mosses: Spatial Patterns in 2010/2011 and Long-Term Temporal Trends in Europe. Technical Report, ICP Vegetation Programme Coordination Centre, Centre for Ecology and Hydrology, Bangor. 